\title{
Foreign Corporate Bonds in the American Market
}

\author{
By Arthur J. Rosenthal \\ Bernhard, Scholle and Company. New York City
}

The Financial Position of the United States

I $\mathrm{T}$ is almost a truism to state that 1 the position of the United States, economically and financially, has completely altered as the result of conditions created by the World War. From an economic point of view, the United States is now the one great country of the world that has in abundance those commodities necessary for the rehabilitation and reconstruction of devastated Europe, and for the up-building and development of other less advanced countries. Financially, the United States is the one remaining large country with sufficient liquid capital to finance not only its own needs but those of other countries as well.

The speeding up of production in the United States during the past few years has been so tremendous that a reservoir of liquid wealth has been created such as was deemed incredible a few years ago. It is not so many years since, when the reproduction of capital in the United States was not sufficiently large to satisfy the growing demands of industry and commerce in our own country, that a large amount of foreign capital had to be utilized for the development of our industries. Our sales of commodities to foreign countries and the liquidation of our indebtedness to foreign creditors have completely reversed the situation. In other words, we are now in a position, from a material point of view, to embark upon a policy of foreign investment. Political and humanitarian considerations urge us forward. It therefore remains to examine such a policy from a practical point of view and to determine what steps are necessary to attract the interest of American investors to foreign government and corporate issues.

\section{Extent of Foreign Loans in America}

Some progress has already been made in the direction indicated. In December, 1913, out of some 2,200 securities quoted on the New York Stock Exchange, there were fifteen foreign issues and practically all of these were the obligations of foreign governments or municipalities. Since that time a number of our allies have placed large loans in this country. A few neutral countries have also placed their issues here and, in addition, substantial amounts of capital have been contributed for the financing of foreign commercial needs through acceptance credits and other credits arranged with our banks. The volume of such loans in the aggregate has been quite substantial, but from the point of view of diversity of issues, very little headway has thus far been made. The New York market, in the strictest sense, is still a domestic market. It has not yet become an international money market where foreign nations and particularly foreign corporations habitually apply for their funds, and, therefore, in no sense does 
it compare with the older established markets abroad, such as London, where, according to available statistics, in 1913 practically 47 per cent of all the issues dealt in were foreign issues.

It is therefore obvious that thus far only a portion of what is required in the nature of international financing has been accomplished. As has been pointed out before, we are the only great country whose capital the ravages of war have not impaired to any appreciable extent. Unless, therefore, we are willing to pursue a policy of isolation, willing to wash our hands of the responsibility of placing a devastated world upon its feet, willing to look out for our own immediate needs first, and for those of the rest of the world afterwards, we shall be obliged to take active measures to participate in international finance to an extent never before realized. It is not only these considerations, however, which urge us forward upon a policy of increased participation in international finance.

\section{The Wisdom of Foreign Invest- MENTS}

\section{Commercial Advantage}

The development of our industries, from a quantitive point of view, as well as from the point of view of technique, has been amazing during the past few years. The production of our commercial and industrial corporations is probably much more than sufficient to supply our normal present domestic needs. It is therefore evident that unless we find other markets for our increasing production, we will be faced with the necessity, when Europe begins to find itself again, of curtailing our production and with the consequent disarrangement of the economic life of the country that such a step would entail.

We must lend financial aid to other countries, if only for the purpose of fostering our own industries. There have been those who have taken the position recently that the lending of money to foreign governments or corporations or individuals does not mean that such funds will necessarily be spent in this country for the purpose of purchasing our products, and it has been pointed out in this connection that the developments in Europe for a decade prior to the war are ample proof of the soundness of their views. England and France during that period were by far the heaviest investors in foreign securities. Germany invested relatively a small amount, and yet, during this same period the foreign commerce and trade of Germany increased to a greater extent than that of either of her two rivals.

It is therefore argued that a similar development may very well occur in this country. In other words, that we will lend our capital but receive no advantages in the way of increased foreign trade. It is essential in analyzing this contention that we bear in mind the changed conditions existing at the present time as compared with those existing prior to the war.

We are the only nation that can supply many of the most necessary commodities in anything like the requisite quantity. Foreign governments and corporations, whether they like it or not, will be compelled to make their purchases in this market. It is not a question of choice. It is a matter of absolute necessity. That this situation may change at some 
time in the future is quite possible, but in the meantime, present conditions will make it possible for the United States to reap, as it were, the entepreneur's profits, and the foothold which she obtains, in addition, in the foreign markets of the world she should be able to maintain, at least in part, even under changed conditions.

Apart from the collateral commercial advantages to be derived by this country from a policy of increasing participation in foreign investments, there are certain direct and very important advantages which this country will derive from such a policy.

\section{Advantages of Diversified Investments}

It is an old axiom that "it is not well to put all one's eggs in one basket." If this country is able to develop and maintain a great body of private investors, whose holdings are diversified and whose interests reach out over the entire world, our financial structure will be a great deal sounder than it would be if our holdings of securities were purely domestic. While the development of means of communication and of closer commercial relations has brought the various countries of the world more closely together than they were formerly, and while the economic conditions prevailing in any one part of the world are usually reflected throughout the entire world, it is undeniable that periods of local depression and unsettlement of business in one country may exist without having exactly the same conditions in other countries. A diversity of interests on the part of the American investor, therefore, will mean a greater stability of return and a sounder condition in our investment structure.

Another advantage to be considered is that such diversity of investments is in the nature of an insurance for the nation. One of the reasons Great Britain was able to get on her feet so quickly after the first shock of the outbreak of the World War was that she was able to mobilize her investments in American securities and resell them to us, thus obtaining funds and credit which would not have been available through any other means. At that time her home securities were practically unsalable; her security investments in allied, and of course in hostile countries, were frozen, but she had sufficient quantities of American securities to enable her, through their liquidation, to withstand the initial shock.

That a similar condition may arise in the future in this country is well within the bounds of belief, and for this reason, if for no other, it would seem to be the part of foresight and wisdom, to have in this country at all times a sufficient amount of securities of other countries to enable us, in times of stress, to turn at least a portion of our investment holdings into cash.

Considerations of humanity and of self-interest both, therefore, seem to dictate that the American investor shall in the future take a greater interest in the securities of foreign governments and corporations than he has heretofore. But it remains to be seen how the American investor can be reached and how foreign investments can be made sufficiently attractive, particularly such issues as foreign corporate bonds. 


\section{Investment Conditions in EURo-} PEAN MaRKets

In forming any opinion in this matter, it will be helpful to examine the situation prevailing in the older European markets with a view to determining whether the conditions there are likely to be duplicated here.

There are no exact statistics available of the holdings of foreign securities in the three European countries that were financially most important prior to the war, namely, England, France and Germany. From estimates which have been made and from opinions expressed by financiers and scientists in Europe prior to the war, it is evident that the most active market for foreign securities was London. Relatively, however, France had the greatest security interests in foreign countries, that is to say, a relatively larger portion of her natural wealth was invested in foreign securities than in the case of England, while Germany, both relatively and absolutely, had the smallest interest in securities of this class.

France- - An estimate was made in 1903 by the French minister of foreign affairs to the effect that at that time the investments of France in foreign securities and enterprises amounted to thirty billions of francs, and were distributed as follows:

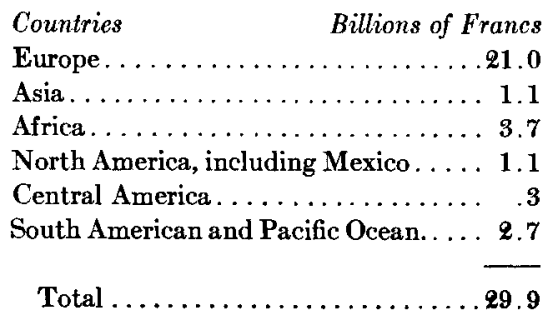

This would mean that around thạt time about one-third of the national wealth of France was invested abroad.

At the end of the year 1910 there were approximately 1,300 securities listed in the official part of the French quotation sheet, of which a little more than 40 per cent were foreign issues. Among these foreign issues, more than 60 per cent were those of governments, municipalities, etc., while of the foreign corporate securities, constituting about 35 per cent of all foreign securities listed, the vast majority were railroad bonds.

England.-Similar statistics are not available for the two other principal European financial countries, viz., England and Germany. Consequently the only figures available that will tend to furnish an approximate illustration of the situation are those referring to the securities listed on the respective stock exchanges, although these, of course, by no means comprise all the foreign securities held in these countries. Approximations, however, are sufficient for our specific purposes.

The total foreign securities listed on the London Stock Exchange in 1914 amounted to a somewhat larger proportion than in France, being approximately 47 per cent of all issues listed. However, among the foreign securities themselves the relation was entirely different. Only approximately 28 per cent of these foreign securities were those of governments, municipalities, etc., while the remainder was constituted by corporate securities, about 42 per cent being those of railroads and public utilities, and about 30 per cent of industrial enterprises. The corporate securities were about equally divided between shares and bonds, the bonds being a trifle more numerous. How- 
ever, among the industrial securities there were practically no bonds, their total aggregating about 8 per cent of all foreign securities listed in London, while the railroad and public utility bonds constituted about 28 per cent.

Germany.-As is evident from previous remarks, the official quotation sheet of Berlin contained by far fewer foreign securities, viz., about 17 per cent. Among the foreign securities there were about 60 per cent of foreign states, municipalities, etc., about 33 per cent railway bonds, and only about 7 per cent shares, chiefly of railways and a few banks, while there were practically no securities of foreign industrial enterprises other than railways.

From the statistics above mentioned, it is evident that the bulk of the foreign financing which has been done in the three chief European money markets has been accomplished primarily by the placing of foreign government or semi-government issues, railroad bonds and by corporate shares, while foreign corporate bonds, other than railroad bonds, have been used to a comparatively slight degree only. It is also evident that a considerable portion of it was dictated by political considerations. Arguing entirely from these premises, therefore, it would seem as though the opportunity for the introduction of foreign corporate bonds in this market was not as great as that for government issues or speculative shares or bonds.

On the other hand, it must be borne in mind that we are living at the present time under entirely different conditions from those prevailing prior to the war. These changed conditions must be taken into consideration in arriving at a conclusion regarding the possible course that the introduction of foreign issues in this market will take.

\section{Bond Buyers in the United States}

We have in this country a comparatively small body of investors in corporate bonds outside of the so-called capitalistic class. The average man in the past has not bought securities. He has deposited his funds in banks and savings banks or has saved through the medium of insurance, if he has saved at all. The result is, that the great mass of corporate bonds held in this country are held by banking institutions, insurance companies and other similar corporations. The appeal must now be made direct to the investor himself. This has been made much easier because of the great amount of educational work that was done in connection with the flotation of the various Liberty Loan issues. A tremendous number of individuals are now owners of United States government bonds who in the past never owned any securities. Very likely because of this we shall find a direct demand on the part of the private investor for corporate bonds such as has not existed heretofore.

Even if this demand should develop, however, it is by no means certain that any material portion of it can be diverted into foreign issues. The rate of return afforded by our domestic corporate bonds is so substantial at the present time that the investor does not feel attracted by the slightly higher yield to be obtained on foreign issues. Other things being equal, he will prefer to have his money invested in securities with the nature of which he is somewhat familiar. Therefore, until domestic corporate bonds yield less 
than they do at present or until foreign corporate bonds yield more, it is probably not in strictly investment foreign corporate bonds that the American investor will take his initial plunge into foreign corporate securities. It is to another class of investor (for he is an investor just as surely as the "rentier") namely, the speculator or pioneer that we shall probably have to look.

\section{The Speculative Investor}

This type of investor is not interested in increasing his income by one or two per cent. He is willing to risk in order to reap larger profits and, naturally, will not ordinarily buy bonds or fixed income bearing obligations of established industries, at least, not for all of his fortune. For a part, and sometimes for all, he prefers securities that carry the possibility of considerable enhancement in capital value. The economic progress in new parts or long neglected parts of the world, has been due to this type of investor. Without him the phenomenal development of our own middle west and far west within less than one lifetime, would have been utterly impossible. The same is true of the progress that has been made, for instance, in some parts of South America during the last two decades, and the same will be true in the case of the tremendous territories now dormant, in the sense of modern economic life, such as China, Siberia and others.

The history of foreign investment markets bears ample testimony to the fact that it was the same class of investor who first took an interest in foreign corporate securities. It has generally been true that the original issues of other than home securities in any financial market, outside of government or quasi-government obligations, such as appeal to the "rentier," have been of such a nature that they carried with them an opportunity for considerable profit rather than a fixed return. Subsequently, as a given proposition or a given country became better known and more developed, it was possible to place bonds or fixed income bearing obligations with the small investor, but usually this was only after the pioneer had blazed the trail.

\section{Factors Favoring Foreign Corpo- RATE Bonds}

Exchange Rates.-The situation likely to govern the introduction of foreign corporate bonds in this country in the near future is, however, entirely different to the conditions which have prevailed in the past in the older countries abroad. We are living in this country in a period that is unique in the history of the world, in that we have never before witnessed such a relatively high value of the dollar as exists today, that is to say, such a depreciation in the moneys of other countries. The pound sterling is selling at approximately 30 per cent discount, the franc at about 65 per cent discount, the lire at about 72 per cent discount and the mark at about 95 per cent discount, while Austrian kronen are selling at even greater depreciation. Because of this situation it becomes possible for the American investor to purchase the fixed interest bearing obligations of foreign countries or of well established enterprises located in well developed coun- 
tries at a price in American dollars which should in the long run show a considerable profit upon his original purchase.

The American investor who today, for example, purchases the soundest corporate bonds of English enterprises, the interest on which has been paid for many years, will have an additional profit of approximately 45 per cent on his investment when exchange again becomes normal. The investor in securities in other countries would, as has been shown, have an even larger profit by virtue of a return of exchange rates to normal.

It would seem, therefore, as though the opportunity were ripe for the introduction in this country of foreign corporate bonds at the present time, with an almost absolute assurance that they would appeal to the American investor, provided he were thoroughly informed of the nature of the security and the possibilities of such investments. This is particularly true because, as has been pointed out, the depreciation in exchange is such that the purchase of investment issues abroad will appeal to that type of investor who wishes to make more than a fixed return upon his money.

Interest Rates.-One of the things which has hitherto retarded the introduction of this type of security in the American market has been the fact that it has been possible for European industries to borrow money more cheaply in their own markets than they could in this country. It has been true, in most of the countries of Europe, even during the war, that interest rates were lower than they were here. There was, therefore, no incentive for the foreign corporations to come to the American money market, nor was there any incentive for the American investor to place his money abroad, owing to the fact that he was able to obtain securities with which he was familiar thát returned a better yield on his money. Up until recently, the various foreign exchanges had not depreciated to such a considerable extent, and therefore this element of attraction, also, was lacking.

This situation is, however, in process of change. The depreciation in foreign exchange above referred to, and the desirability of obtaining credits in the United States for the purchase of commodities has made it exceedingly desirable for foreign corporations to do at least a portion of their borrowing in the American market. For such borrowings, the present condition of the exchange market makes it possible for them to pay a considerably higher rate of interest than they could under normal conditions, and a considerably higher rate of interest than American corporations could afford to pay for similar. loans. There is, therefore, every prospect that for this reason, if for no other, foreign corporations will compete with domestic concerns for capital in the American money markets.

European Interest Rates.-Moreover, since the end of the war there has been an upward movement in interest rates throughout Europe so that the level there at the present time is approximately that prevailing in this country or higher. Owing to the tremendous demand for capital and credit arising from the process of rehabilitation and reconstruction, it is practically a foregone conclusion that interest rates in the European money markets will advance still further. It will then 
become profitable for foreign industries, other than those requiring dollar credits, to turn to the American money market. It will then become necessary for them also to compete with our domestic issues, and this should bring about an increase in the interest return to the American investor which is certain to arouse his interest. When this situation is considered in conjunction with the possibilities arising from the depreciated condition of foreign exchange, it would seem as though we had arrived at a place where we were about ready to consider actively the possibility of introducing foreign corporate issues here.

\section{Public Interest in Foreign Situations}

In order to obtain the best possible results, it will be necessary that the American investor be fully informed of the nature of the security which is offered him, of the conditions prevailing in the countries containing the industries whose securities are being offered, and, in general, that he should become familiar with the exact status of his proposed investment.

For this, it will be necessary to have the newspapers and other publications of this country give a great deal more space and attention to foreign conditions than they have heretofore. One of the results of the Great War has been to arouse the interest of the American people in the doings of other lands and to increase their fund of information regarding various foreign governments and the conditions prevailing in other countries. This state of mind of the American people, if it is fostered by responsible publications, should lead to a more exact knowledge of conditions in foreign countries, and, therefore, to a greater interest in the securities originating there, and this should be one of the elements which will make possible an increasing participation by American investors in foreign securities.

\section{The Small Investor and Foreign SECURITIES}

There is another development which has come about recently which should tend to bring about an increased participation of American capital in international finance. Even granted that the average American investor is fully informed of the relative merits of foreign securities, it still remains true that the investor of moderate means has not a sufficient amount of capital at his disposal to diversify properly his risks. It may very well happen that one or two of a stated number of foreign investments turn out to be worthless. On the other hand, if an individual's holdings are sufficiently diversified he will still be in a position to reap substantial profit on his total holdings, by virtue of the fact that the remainder return him an unusual profit. Some means should, therefore, be devised to enable the small investor to diversify his holdings. A beginning has already been made here in the formation of investment companies, the purpose of which is to purchase foreign securities, something along the lines of the Scottish investment trusts. The Scottish investment trusts usually issued their own obligations to their investors and with the proceeds thereof purchased the obligations of foreign governments and foreign industries, so diversifying their holdings that the risks were comparatively slight and the 
possibilities for profit considerable. set. That there are still many obstaSeveral similar companies have been cles to be overcome is undeniable; formed recently or are in process of that a vast amount of educational formation, and the prospects are that a great many more will ultimately be brought into being, thus providing the somewhat indirect but very important method of enabling the small investor to participate in foreign investments on a rather safe basis, namely, by securing a diversification of interests and selection based upon expert knowledge.

From the evidence that has been adduced, it would seem as though the time were at hand when the American investor can and will purchase foreign corporate securities. The stage is work must be done is evident. The process of orientation in the light of changed conditions will of necessity be gradual, but we will find ourselves ultimately. To this end we will require the utmost coöperation by all far-seeing elements of the country. Nationalism and internationalism in finance are not two opposed and hostile ideas; they go hand in hand; and this is the doctrine that must be preached and accepted if America is to seize and hold her rightful heritage-the material and moral leadership in world affairs. 